\title{
Hepatitis A Virus Cellular Receptor 1
}

National Cancer Institute

\section{Source}

National Cancer Institute. Hepatitis A Virus Cellular Receptor 1. NCI Thesaurus. Code C116608.

Hepatitis A virus cellular receptor 1 (359 aa, $~ 39 \mathrm{kDa}$ ) is encoded by the human HAVCR1 gene. This protein is involved in the modulation of asthma and allergic reactions. 